Review

\title{
Corpse Management in Social Insects
}

\author{
Qian Sun and Xuguo Zhou $\bowtie$ \\ Department of Entomology, University of Kentucky, Lexington, KY 40546-0091, USA. \\ $\triangle$ Corresponding author: Dr. Xuguo "Joe" Zhou, Department of Entomology, University of Kentucky, S-225 Agricultural Science Center \\ North, Lexington, KY 40546-0091. Phone: 859-257-3125 Fax: 859-323-1120 Email: xuguozhou@uky.edu. \\ (c) Ivyspring International Publisher. This is an open-access article distributed under the terms of the Creative Commons License (http://creativecommons.org/ \\ licenses/by-nc-nd/3.0/). Reproduction is permitted for personal, noncommercial use, provided that the article is in whole, unmodified, and properly cited.
}

Received: 2012.12.29; Accepted: 2013.02.21; Published: 2013.03.22

\begin{abstract}
Undertaking behavior is an essential adaptation to social life that is critical for colony hygiene in enclosed nests. Social insects dispose of dead individuals in various fashions to prevent further contact between corpses and living members in a colony. Focusing on three groups of eusocial insects (bees, ants, and termites) in two phylogenetically distant orders (Hymenoptera and Isoptera), we review mechanisms of death recognition, convergent and divergent behavioral responses toward dead individuals, and undertaking task allocation from the perspective of division of labor. Distinctly different solutions (e.g., corpse removal, burial and cannibalism) have evolved, independently, in the holometabolous hymenopterans and hemimetabolous isopterans toward the same problem of corpse management. In addition, issues which can lead to a better understanding of the roles that undertaking behavior has played in the evolution of eusociality are discussed.
\end{abstract}

Key words: undertaking behavior; necrophoresis; eusociality; Hymenoptera; Isoptera.

\section{Introduction}

Social animals regularly face death of their group members. Species from diverse taxa recognize corpses and modify their behavior to reduce potential deleterious health effects. For example, the general awareness and prolonged curiosity exhibited toward dead individuals has been observed in elephants [1], and necrophagy of conspecifics occurs in various species of mammals, reptiles, amphibians, fishes and crustaceans [2]. Sanitary issues caused by exposure to corpses are universal, but especially in social organisms living in enclosed nests with dense populations, which make them vulnerable to contagious pathogens and parasites [3]. To maintain healthy colonies, eusocial hymenopterans (bees, wasps, ants) and isopterans (termites) have evolved sophisticated mechanisms to counter the threat of epidemic disease at both the individual and colony level, including active immune responses and behavioral adaptations [3, 4]. Corpse management, also anthropomorphically known as undertaking behavior, is one of the most intriguing innate behaviors in social insects [5-7].
Responses to corpses vary in insects with different level of sociality, including solitary (no shared nesting site, no parental care), gregarious (shared nesting site), and eusocial (overlap of generations, reproductive division of labor, and cooperative brood care). In some solitary or gregarious insect species (e.g. cockroaches, springtails), the response to a dead or injured conspecific is usually avoidance $[8,9]$. In social spiders (gregarious) [10] and a social aphid (arguably eusocial), Pemphigus spyrothecae Passerini [11], disposing of the dead is simply a part of nest cleaning because it is indistinguishable from dealing with inanimate nest waste. In species of the two extensively-studied eusocial lineages, Hymenoptera (ants, bees, and wasps) and Isoptera (termites), corpse management is distinctive and differs from other nest cleaning behaviors such as disposing of feces and decaying food remains [6, 12, 13]. Facilitated with different behavioral repertoires (e.g., removal, burial, and cannibalism), honey bees, ants, and termites have evolved complex systems of corpse management 
dealing with corpses of different ages, origins, and infection status [7, 14-16]. Although the specific components of corpse management are distinctly unique in various taxa of eusocial insects, the evolution of a complex strategy for dealing with the dead is a shared characteristic of eusociality.

In social insects, undertaking behavior is a sequential array of corpse-induced behavioral responses that target potential health-related hazards to maintain colony fitness. Among many responses to corpses, one of the earliest and well described in social insects is necrophoresis, which refers to the removal of dead individuals from the nest. The term necrophoresis was defined by Wilson et al. [5], which originated from Greek (necros refers to the dead and phoresis means transport) [15]. Necrophoric behavior is interchangeable with undertaking behavior in some literature. Here, we use undertaking behavior as a broad term that includes corpse removal from the nest, burial (covering the dead with soil and/or other materials), cannibalism (intraspecific necrophagy), and avoidance (preventing contagion by intentionally avoiding areas where the dead are located), a behavior sometimes considered as necrophobia.

The phenomenon of undertaking behavior resulted in anthropomorphic descriptions by early naturalists, such as "funerals" and "cemeteries" in honey bees [6] and ants $[17,18]$. In-depth study of behavioral patterns associated with undertaking did not start until 1958, when Wilson et al. first identified the chemical cue eliciting undertaking behavior in two ant species, Pogonomyrmex badius (Latreille) and Solenopsis saevissima (Smith) [5]. To date, studies of undertaking behavior have been focused on three aspects: death recognition cue, behavioral process, and division of labor. Recently, there have been renewed interests in undertaking behavior in termites focusing on death cues and behavioral responses [7, 19-21]. Despite studies for over 50 years, the genetic underpinning of undertaking behavior is still not well understood. Some aspects of undertaking behavior are shared by the phylogenetically distant eusocial hymenopterans and isopterans, e.g., recognition/differentiation of the dead from the living. This review provides 1) an overview of undertaking behavior, focusing on death recognition, behavioral responses, and task allocation as they relate to dealing with the dead, 2) a comparison of adaptations in different eusocial groups, specifically, Hymenoptera and Isoptera, and 3) prospects for future studies.

\section{Death recognition and elicitation of un- dertaking behavior}

Once individuals die in the active area of a social colony, colony members need to distinguish the dead from the living before taking any action. Death recognition depends on diverse cues, including chemical, tactile (e.g., shape and texture), and possibly visual input. Recognition of the dead has been widely shown to be achieved through chemical cues, explained by two primary hypotheses, "fatty acid death cue" [5] and "chemical vital sign" [12].

Pioneering studies on the nature of undertaking stimuli conducted by Wilson and his colleagues [5] in two ant species, Pogonomyrmex badius and S. saevissi$m a$, suggested that fatty acids, particularly oleic acid accumulating in dead bodies, trigger undertaking responses. This conclusion was confirmed later in other ant species [22]. The idea of a "fatty acid death cue" eliciting undertaking responses has been widely accepted for decades [23, 24]. However, certain aspects of undertaking behavior could not be explained by this hypothesis alone. Gordon found that oleic acid released foraging as well as undertaking behavior in Pogonomyrmex badius, depending on the social activities of the colony at a given time [25]. The rapid recognition and the subsequent response to corpses (within 1 hour) by nestmates indicate that decision-making time is too brief to allow decomposition and the release of a fatty acid death cue in the red imported fire ant, Solenopsis invicta Buren [26] and in honey bee, Apis mellifera Linnaeus [6]. Therefore, it was suggested that chemical(s) associated with life might inhibit a pre-existing undertaking releaser [6, 26]; and the "chemical vital sign hypothesis" was first demonstrated by Choe et al. [12] in the Argentine ant Linepithema humile (Mayr). Reductions in the quantity of two cuticular chemicals, dolichodial and iridomyrmecin on live workers, plays a more important role in inducing undertaking responses. Triglycerides were identified to be pre-existing chemicals inducing both necrophoresis and aggression [12]. The "chemical vital sign" hypothesis suggests an adaptive response toward freshly dead/killed individuals in insect societies. Instead of waiting for the release of "fatty acid death cue", social insects living in dense populated colonies rely on the "chemical vital sign" to recognize dead individuals and elicit appropriate undertaking responses before the decomposition of corpses. This adaptation is not uncommon, and it is consistent with what typically happens in many species of vertebrates, in which dead individuals are recognized instantly according to the absence of signals associated with life, such as lack of movement or response to stimuli.

In comparison to ants, neither a "fatty acid death cue" nor a "chemical vital sign" has been determined in honey bees. However, Visscher [6] suggested that a 
chemical signature was present immediately after the death. In addition, visual, auditory, and thermal cues were excluded in honey bees due to the facts that undertaking behavior took place in darkness, and removal activity was reduced to minimal when corpses were extracted with solvent or coated with paraffin [6]. In Isoptera, the mechanism of undertaking elicitation has been recently studied in a fungus-growing termite, Pseudacanthotermes spiniger (Sjöstedt). The burial behavior in Pseudacanthotermes spiniger was triggered by a blend of indole, phenol, and fatty acids [19], which, at least in part, supported the "fatty acid death cue" hypothesis. In the eastern subterranean termite, Reticulitermes flavipes (Kollar), however, the "chemical vital sign" hypothesis could not be excluded based on our observation that workers showed an immediate response $(<15 \mathrm{~min})$ toward freshly killed nestmates [27]. In a congeneric species, $R$. virginicus (Banks), Ulyshen and Shelton (2012) suggested that fatty acids (e.g., oleic acid) and tactile cues synergistically induce burial behavior. This is the only case in which a tactile cue was implicated; however, tactile cues alone have not been found to be effective. Termite workers are sensitive to light [28, 29], however, the involvement of visual cues is unlikely to be a major factor in the subterranean termites because undertaking behavior is independent of light-dark regime [20, 21, 27].

The term "necromone" has been used to describe death-recognition chemicals [9]. Fatty acids are a common recognition mechanism for death in arthropods. Oleic acid and linoleic acid are the two major unsaturated fatty acid compounds to induce undertaking behavior in ants $[5,22,26]$ and avoidance in a wide range of arthropods including terrestrial Isopoda, Collembola, cockroaches, and social caterpillars, and these compounds are considered to be conserved necromones $[8,9]$. Fatty acids have limited volatility and are derived from corpses or injured cells by enzymatic or bacterial processes, and serve as reliable cues for risks including predation and disease across wide phylogenetic ranges [9]. Interestingly, American cockroaches, Periplaneta americana (Linnaeus), are repelled (necrophobic behavior) by oleic acid $[8,30]$. In contrast, termites, regarded as "eusocial cockroaches" [31], perform burial behavior in response to the same chemical [20]. A similar situation occurs in Hymenoptera in that solitary bees avoid foraging sites where dead conspecifics are present [32,33], whereas honey bees remove corpses out of nests [6]. As fatty acid necromones are associated with injury and death caused by predation or contagion, effective recognition of these chemicals might benefit other non-social insects as well.
In summary, recognition of death through chemical cues is shared by honey bees, and many ant and termite species, but the specific chemical signals remain unclear in most species. Oleic acid is the only known common death signal recognized by some insects, whereas it is unknown whether other chemical signatures of death are shared among eusocial hymenopterans and isopterans. Two hypotheses, "fatty acids death cue" and "chemical vital sign", are not mutually exclusive. In addition to the "fatty acid death cue" and "chemical vital sign" hypotheses, it might well be expected that: 1) recognition of fatty acid death cues is an evolutionary conserved response from non-eusocial ancestors to avoid the dead, whereas undertaking is a derived behavioral trait in eusocial insects; and 2) death recognition through diminished chemical vital sign might be an evolutionary novelty in some eusocial insects, which enables workers to respond rapidly to prevent pathogen transmission. Besides chemical cues, the role of tactile cues needs to be studied in most social insects to fully understand elicitation of undertaking behavior.

\section{Behavioral responses toward corpses}

Eusocial Hymenoptera and Isoptera share the common features of group-living that make them vulnerable to pathogens and parasites, and consequently, they have evolved undertaking behaviors, individually, to mitigate hazards [3]. Specific behavioral patterns, however, vary among different social groups. Once death cues are recognized, social insects respond to the dead differently. Corpse removal (necrophoresis in a narrow sense) is prevalent in honey bees [6] and ants [5, 22, 34], although burial (covering the dead) [15] and cannibalism (intraspecific necrophagy) [35] were also documented in ants. In contrast, undertaking responses are more complex in termites than eusocial hymenopterans [7].

Studies of undertaking behavior in bees have traditionally focused on the honey bee, Apis mellifera $[6,36]$. Honey bees dispose of nestmate corpses in a straightforward manner, i.e., corpse removal (Fig. 1C). This behavior pattern is a part of their behavioral repertoire [6, 37]. An "undertaker" bee typically antennates the dead bee briefly, grasps its appendages with mandibles, transports it outside, and drops it from the hive, while other debris in honey bee colonies is removed less rapidly [6].

The behavioral patterns of ants are extremely diverse, and they are known to keep the interior of their nest meticulously clean. Corpse removal (Fig. 1B), a common undertaking strategy in various ant species, is distinguished from other nest cleaning behaviors as corpses are transported more rapidly and 
over greater distances than inanimate objects $[5,25$, 38]. Ants transport corpses to certain sites, depending on the species. Carrying dead nestmates outside and discarding them on refuse piles (or kitchen middens) have been observed in the myrmicine ants Pogonomyrmex badius and S. saevissima [5], bull ants Myrmecia vindex Smith [22], red imported fire ant $S$. invicta [26], army ants Eciton [39], Argentine ants L. humile [12], and common red ant, Myrmica rubra (Linnaeus) [40]. Leaf-cutter ants of the genus Atta, however, remove them to special refuse chambers [41, 42]. Corpse removal has also been reported in several other ant species such as the desert leaf-cutter ant Acromyrmex versicolor (Pergande) [34] and another species Temnothorax lichtensteini (Bondroit) [15]. Cannibalism of dead individuals was observed in the myrmicine ants of genera Pheidole and Solenopsis, the weaver ants Oecophylla [17], and the red wood ant Formica rufa (Linnaeus) [43]. In the red imported fire ant S. invicta, cannibalism was occasionally observed at refuse piles in the field [26]. The red wood ant, Formica polyctena Foerster, eat their defeated enemies after intercolony battle, which has been considered to be adaptive as $F$. polyctena practices cannibalism behavior more frequently during period of food shortage [35, 44]. Cannibalism of the dead is not a predominant corpse management strategy in ants, but corpses could elicit foraging behavior and be consumed by neighboring scavenging species [5, 26]. Besides cannibalism, ants are reported to perform burial behaviors using soil and nest material in response to corpses[17] such as in T. lichtensteini, but it is less common probably because the energy input of burial activity is higher than corpse removal [15]. Another prophylactic strategy noticeable in ants is that moribund individuals leave their nests to die alone, as reported in Temnothorax unifasciatus (Latreille) [45, 46].

Undertaking behavior performed by subterranean termites can circumvent soil termiticide-based "barrier" treatment [47-50]. Most recently, an influx of studies have shown a complex series of undertaking behaviors in termites, including burial, avoidance, and cannibalism [7, 19-21]. Cannibalism of the dead in termites was considered to be a mechanism of recycling nitrogenous nutrients[47, 51], which is, in part, due to their nutritionally poor cellulosic diet[52]. Coptotermes formosanus Shiraki show cannibalism of cadavers when starved [53]. In another lower termite species Reticulitermes speratus (Kolbe) and a higher termite Microcerotermes crassus Snyder, living nestmates consume freshly dead and/or injured termites [7]. A precursor of necrophagy or cannibalism has been observed in subsocial woodroach species, Cryptocercus punctulatus Scudder and Cryptocercus kyebangensis Grandcolas [54, 55]. In termites, cannibalism also functions as a hygienic strategy because by consuming the corpses it destroys the source of pathogens. The dampwood termite, Zootermopsis angusticollis (Hagen), eat both dead and diseased individuals, with higher chances of cannibalism toward the ones with higher spore concentrations of the entomopathogenic fungus, Metarhizium anisopliae (Metchnikoff) [56]. In R. flavipes, workers ingest harmful fungal masses of Metarhizium anisopliae while grooming nestmates and the conidia are inhibited through the alimentary tract [57]. It is also common that termites bury fungi-killed nestmates and old corpses to physically isolate them from the healthy nestmates [7, 16, 48, 49]. When challenged with the fungus Metarhizium anisopliae, Coptotermes formosanus displays undertaking behavior in a density dependent manner in which corpses would be cannibalized preferentially at a low level of mortality, while at higher level of mortality, burial was predominant [21]. In a fungus-growing species, Pseudacanthotermes spiniger, dealates buried the dead to prevent potential pathogen outbreak in the initial chamber [19], while in $R$. virginicus, the existence of insect corpses induces building behavior to separate the dead from the rest of the colony, which is also a form of burial [20]. In comparison to ants and bees, the propensity of termites for tunnel building plays an important role in their burial behavior [50]. In addition, the use of fecal material, chewed material or soil coated with saliva for burial provides antifungal components that act as further protection against fungal growth $[19,50]$. In the case of fungi-killed corpses in Coptotermes acinaciformis (Froggatt) [58], and insecticide-killed (including fipronil and thiamethoxam) individuals in Coptotermes formosanus [49], termites have been observed to intentionally avoid dead individuals. Corpse removal seems less likely to be an end response in termites, as they do not have certain chambers or refuse piles that serve as waste storage sites, and they rarely leave their nests. Instead, corpse removal (Fig. 1A) is more likely to be a part of the dynamic process associated with other undertaking behaviors - corpses carried by workers would be eventually consumed or buried.

In addition to cannibalism and corpse burial, other behaviors including alarming, grooming, recruitment and aggression interact synergistically during undertaking processes[7, 16, 50]. When encountering a congeneric corpses, $R$. flavipes soldiers showed aggression and guarding behavior, while both worker and soldier castes exhibited strong recruitment activity [27]. Similarly, when fungal infection occurred, $R$. flavipes workers also aggregated and actively recruited fellow workers to cope with the 
infected individuals [16]. Alarm behaviors in termite workers, characterized by oscillatory vibration and/or rapid walking to generate substrate-borne vibrations, are performed to alert or attract other colony members in the presence of competitors, predators, and entomopathogens $[16,59,60]$. In $\mathrm{Na}$ sutitermes termites, alarm pheromones have been identified in termite soldiers to function in recruitment of soldiers for colony defense [61, 62]. However, the sensory mechanisms of recruitment have yet to be determined.

\section{Differential undertaking responses}

Honey bees, ants, and termites often show species-specific undertaking responses toward corpses (Figure 1 and Table 1). Ants and termites also exhibit plastic responses to the nature of the corpses, including their postmortem time (age, indicator of decomposition status), infection status (whether harmful fungi are present), and origin (whether or not the corpse is a nestmate or of the same species). Honey bees removed $1 \mathrm{~h}$ old corpses more quickly than freshly killed individuals [6], however, an undertaking response to corpses with longer postmortem time was not investigated. Dead ants in F. rufa were consumed for food, but infectious ants were avoided [43]. In T. lichtensteini, workers discriminate old corpses from freshly killed individuals, with new corpses buried while old ones are transported outside [15]. Differential behavior patterns have been observed in subterranean termite species. Colonies of $R$. virginicus were found to isolate fungal infected individuals by burying the dead onsite, while the healthy corpses were cannibalized [47]. Coptotermes formosanus has been reported to attack, cannibalize and bury fungus-inoculated workers more frequently than uninoculated workers [63]. In Coptotermes formosanus and $R$. speratus, only new corpses and injured nestmates were cannibalized, whereas aged corpses were buried. In R. flavipes, conspecific corpses were taken back to the nest and possibly consumed, while workers opted to bury corpses of a congeneric species $R$. virginicus onsite with an additional colony defensive purpose [27]. Soldiers were also involved with guarding and attacking of congeneric corpses as the burial response was underway [27].

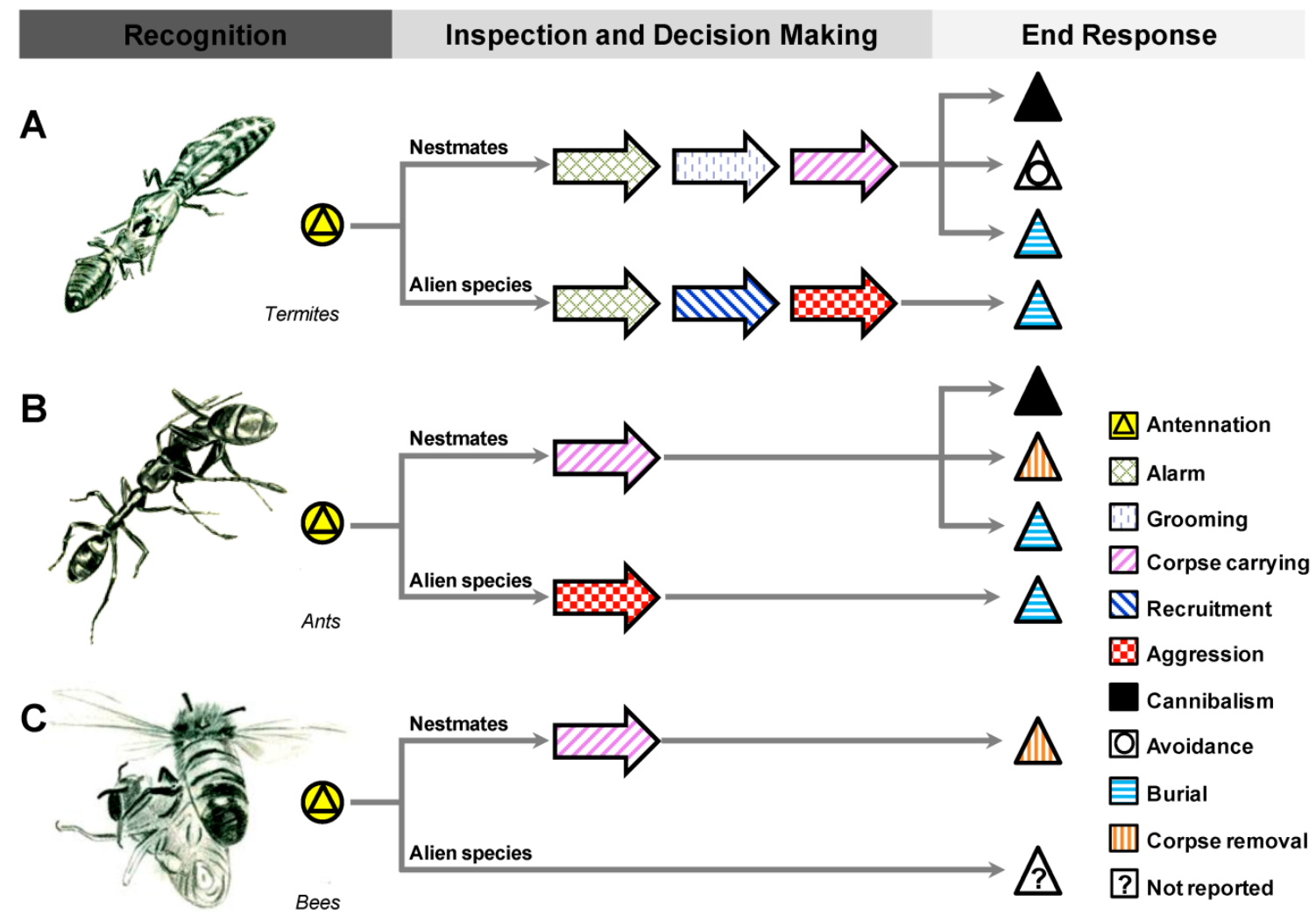

Figure I. Undertaking process displayed by different social insects. A represents a termite worker dragging a dead nestmate; B shows an undertaker ant carrying a dead nestmate out of the nest; and $\mathbf{C}$ illustrates an undertaker bee removing a dead drone. Reticulitermes flavipes, Linepithema humile, and Apis mellifera are the representative species for termites, ants, and bees, respectively. Undertaking process involves three phases including recognition, inspection and decision making, and end behavioral responses. Illustrated by Zhou, $\mathrm{X}$. 
Table I. Current knowledge of the undertaking process in Hymenoptera and Isoptera.

\begin{tabular}{|c|c|c|c|c|}
\hline \multicolumn{2}{|c|}{ Undertaking Process } & \multicolumn{2}{|l|}{ Hymenoptera } & \multirow{2}{*}{$\begin{array}{l}\text { Isoptera } \\
\text { Termites }\end{array}$} \\
\hline Phase & Behavior & Bees & Ants & \\
\hline Recognition & Antennation & Apis mellifera & Most species & Most species \\
\hline \multirow{5}{*}{$\begin{array}{l}\text { Inspection and } \\
\text { decision making }\end{array}$} & Alarm & $\mathrm{NR}^{*}$ & NR & Reticulitermes flavipes $[16,50]$ \\
\hline & Grooming & NR & Pogonomyrmex badius [5] & $\begin{array}{l}\text { Reticulitermes flavipes [16]; } \\
\text { Coptotermes formosanus [7]; } \\
\text { Reticulitermes speratus [7]; } \\
\text { Microcerotermes crassus [7] }\end{array}$ \\
\hline & Corpse carrying & Apis mellifera [6] & $\begin{array}{l}\text { Pogonomyrmex badius [5]; } \\
\text { Solenopsis saevissima [5]; } \\
\text { Myrmecia vindex [22]; } \\
\text { Solenopsis invicta [26]; } \\
\text { Eciton [39]; Linepithema humile [12]; Atta } \\
\text { texana [41, 42]; Acromyrmex versicolor [34]; } \\
\text { Temnothorax lichtensteini [15] }\end{array}$ & $\begin{array}{l}\text { Coptotermes formosanus [49]; } \\
\text { Reticulitermes flavipes [27] }\end{array}$ \\
\hline & Recruitment & NR & Solenopsis invicta [26] & Reticulitermes flavipes [16] \\
\hline & Aggression & NR & Temnothorax lichtensteini [15] & Reticulitermes flavipes [16]; \\
\hline \multirow[t]{4}{*}{ End response } & Cannibalism & NR & $\begin{array}{l}\text { Formica rufa [43]; Solenopsis invicta [26]; } \\
\text { Pheidole; Oecophylla }[17] ; \\
\text { Formica polyctena }[35,44]\end{array}$ & $\begin{array}{l}\text { Reticulitermes sp. [47]; } \\
\text { Zootermopsis angusticollis [56]; Coptotermes } \\
\text { formosanus [7]; Reticulitermes speratus [7]; } \\
\text { Microcerotermes crassus [7] }\end{array}$ \\
\hline & Avoidance & NR & NR & $\begin{array}{l}\text { Coptotermes acinaciformis [58]; Coptotermes } \\
\text { gestroi [83] }\end{array}$ \\
\hline & Burial & NR & Temnothorax lichtensteini [15] & $\begin{array}{l}\text { Reticulitermes flavipes [16, 27, 48]; Reticu- } \\
\text { litermes virginicus [20]; Pseudacanthotermes } \\
\text { spiniger [19]; Coptotermes formosanus [7, } \\
\text { 49];Reticulitermes speratus [7]; Microcero- } \\
\text { termes crassus [7]; Globitermes sulphureus [7] }\end{array}$ \\
\hline & Corpse removal & Apis mellifera [6] & $\begin{array}{l}\text { Pogonomyrmex badius [5]; } \\
\text { Solenopsis saevissima [5]; } \\
\text { Myrmecia vindex [22]; } \\
\text { Solenopsis invicta [26]; } \\
\text { Eciton [39]; Linepithema humile [12]; Atta } \\
\text { texana [41, 42]; Acromyrmex versicolor [34]; } \\
\text { Temnothorax lichtensteini }[15]\end{array}$ & $\mathrm{NR}$ \\
\hline
\end{tabular}

* NR: Not Reported.

Undertaking responses are, in part, dependent upon the feeding habit and nest ecology in a given species, and also the risk associated with corpses [7]. Postmortem time of corpses is associated with the decomposition of the dead, indicating whether they are valuable for recycling in species practicing cannibalism [7]. Fungi infection is common in both ants and termites, which react accordingly to prevent epidemic outbreaks within their respective colonies [3]. The presence of non-nestmate corpses could be signals of competition, predation, or disease [27]. Therefore, through corpse management, social insects mitigate disease hazard [6, 7, 22]; and in termites, it brings additional incentives for recycling nutrients and contributing to colony defense [27]. Further research is needed to determine the chemical signature of corpses and mechanisms of decision-making during the complex undertaking processes.

\section{Task allocation of undertaking behavior}

Reproductive division of labor and subsequent task allocation are characteristics of the eusociality. Based on their morph and age, mechanisms underlying the division of labor in the non-reproductive worker caste can be summarized into physical polymorphism and age polyethism [64]. In addition, workers in some species show considerable behavioral plasticity in task allocations and partition their work force to meet the specific demands of a colony [65]. This flexibility is critical to the growth and survival of a colony, especially for disease management and colony defense. Undertaking behavior is performed by the worker castes [66], primarily due to their capability of corpse recognition. Not surprisingly, sensitivity to oleic acid is caste-specific in a leaf-cutter ant Atta mexicana (Smith), where workers are responsive but soldiers are not [67]. The study of 
task specialization on undertaking behavior has been focused on whether there is worker polyethism and how it is regulated.

As a part of honey bees' repertoire, undertaking behavior was first reported to be specialized by a small group of workers that comprise only $1 \%-2 \%$ of the colony population [6]. Domination of the task by a few active individuals is frequently demonstrated in the literature with the longest recorded tenure of removing 114 corpses over a 13 day period by an extreme specialist [37]. In honey bee colonies, both age polyethism and genetic variation influence division of labor among workers. Undertaker bees are middle-aged workers, which are more likely to act on corpse removal during their entire pre-foraging career than other workers of the same age [68]. Genetic effects suggest lifetime differences in behavior preference in honey bee, and genetic factors constrain colony-level plasticity for undertaking behavior, given the fact that removal of undertakers failed to result in task-switching by other workers [69]. Such a result excludes the possibility of the "genotypic threshold model" proposed by Robinson and Page [70], which predicts that commonly a task will be performed by worker specialists with the lowest response threshold that is genetically influenced, while more workers with higher thresholds switch to this particular task with increased stimulation, i.e., a feedback loop of task regulation. Task specialization of undertaking behaviors occurs similarly in ant colonies, as reported in the desert leaf-cutter ant Acromyrmex versicolor in which genetic variation affects worker task performance $[34,71]$. Both honey bee and desert leaf-cutter ant colonies are maintained by multiple mating events or multiple queens. This enriched genetic diversity increases the probability of having undertaking behavior in their behavioral repertoire at the colony level.

Learning and memory have not been suggested to be important components of corpse removal in honey bee, because undertakers demonstrated no obvious improvement with experience [68]. In contrast, in the common red ant Myrmica rubra, undertaker ants behaved as short-term specialists, and they disposed of dead bodies to specific locations (cemeteries) based on spatial memory [40]. Emergent worker polyethism in Hymenoptera is affected by colony size, with increased group size leading to efficient allocation of individuals to different tasks (specialists) to meet colony demand [72-74]. Polyethism is likely the mechanism to govern undertaking specialists in some ants that live with heterogeneous surroundings. Complex cues could be present concurrently in a large ant colony, therefore focusing on one task by specialists prevents inappropriate task-switching leading to high fitness cost. For example, a single decomposition compound, oleic acid, can elicit both foraging and undertaking responses [25].

In hemimetabolous termites, there have been no reports of task specialization of undertaking behavior. Intercaste flexibility is reported in a pleometrotic termite species Pseudacanthotermes spiniger, in which dealates performed corpse-burial behavior in the initial chamber before the first generation of workers develops [19]. In addition, termites employ various strategies such as removal, burial, cannibalism and corpse avoidance (Fig. 1), which makes it difficult to define "undertakers". The totipotent worker caste in termites is considered immature, whereas the worker caste in holometabolous ants, bees, and wasps is a developmental end (adult). Therefore, age polyethism in hemimetabolous termites includes both polyethism between different instars and age of the last instar [75]. Large workers of Reticulitermes fukienensis Light, undertake most tasks including corpse burial, but behavioral plasticity is present with all sized workers being able to perform the task [76]. In higher termites, however, there is evidence of age polyethism [77, 78], but whether undertaking behavior is amongst the age-related behaviors has not been determined.

\section{Perspectives and future research}

There is renewed interest in undertaking behavior, especially defining behavioral responses [7, $21,27]$ and sensory cues $[19,20]$. However, task allocation during the undertaking process is poorly understood. Since the worker caste in lower termites can be considered as "generalist" [66, 76], activation of reserve labor is a possible mechanism to compensate for the lack of specialists in lower termites. Activation of reserve labor has been documented in honey bees $[79,80]$ and ants $[81,82]$, and it was also implicated in a higher termite, Nasutitermes exitiosus (Hill) [75]. The role of reserve labor in the lower termites, however, has yet to be investigated.

Despite the differences in division of labor and task allocation, both eusocial hymenopterans and isopterans manage corpses effectively. In both holometabolous hymenopterans and hemimetabolous termites, the genetic underpinnings of undertaking responses remain an unsolved mystery and warrant further investigation. Given that undertaking behavior is one of the characteristics shared among eusocial groups, comparative studies in diverse eusocial lineages using integrative approaches involving behavioral observation, chemical ecology, genomic and functional genomic analyses will shed light on the proximate mechanisms of eusociality. 


\section{Acknowledgements}

The authors are grateful to two anonymous reviewers and the editor for their constructive criticisms. Special thanks go to Drs. John Obrycki and Kenneth Haynes (Department of Entomology, University of Kentucky) for their comments on an earlier draft. This research was supported by a start-up fund from the University of Kentucky, the NSF-EPSCoR Research Scholars Program, Kentucky Initiative in Ecological Genomics (Award Agreement No. NSF/EPSCoR RII Grant EPS-0814194), and a grant from the Kentucky Commercialization Fund Program, Kentucky Science and Technology Corporation (Award Agreement No. KSTC-144-401-09-034). The granting agencies have no role in the study design, data collection and analysis, decision to publish, or preparation of the manuscript. The information reported in this paper (No. 13-08-021) is part of a project of the Kentucky Agricultural Experiment Station and is published with the approval of the Director.

\section{Competing Interests}

The authors have declared that no competing interests exist. All authors read and approved the final manuscript.

\section{References}

1. Douglas-Hamilton I, Bhalla S, Wittemyer G, Vollrath F. Behavioural reactions of elephants towards a dying and deceased matriarch. Appl Anim Behav Sci. 2006; 100(1-2): 87-102.

2. Rudolf VH, Antonovics J. Disease transmission by cannibalism: rare event or common occurrence? Proc R Soc London, Ser B. 2007; 274(1614): 1205-1210.

3. Cremer S, Armitage SA, Schmid-Hempel P. Social immunity. Curr Biol. 2007; 17(16): 693-702.

4. Konrad M, Vyleta ML, Theis FJ, et al. Social transfer of pathogenic fungus promotes active immunisation in ant colonies. PLoS Biol. 2012; 10(4): e1001300.

5. Wilson EO, Durlach NI, Roth LM. Chemical releaser of necrophoric behavior in ants. Psyche. 1958; 65(4):108-114.

6. Visscher PK. The honey bee way of death: Necrophoric behaviour in Apis mellifera colonies. Anim Behav. 1983; 31(4): 1070-1076.

7. Neoh KB, Yeap BK, Tsunoda K, Yoshimura T, Lee CY. Do termites avoid carcasses? Behavioral responses depend on the nature of the carcasses. PLoS One. 2012; 7(4): e36375.

8. Rollo CD, Czvzewska E, Borden JH. Fatty acid necromones for cockroaches. Naturwissenschaften. 1994; 81(9): 409-410.

9. Yao M, Rosenfeld J, Attridge S, et al. The ancient chemistry of avoiding risks of predation and disease. Evol Biol. 2009; 36(3): 267-281.

10. Tietjen WJ. Sanitary behavior by the social spider Mallos Gregalis (Dictynidae): Distribution of excreta as related to web density and animal movements. Psyche. 1980; 87(1-2): 59-73.

11. Benton TG, Foster WA. Altruistic housekeeping in a social aphid. Proc R Soc London, Ser B. 1992; 247(1320): 199-202.

12. Choe DH, Millar JG, Rust MK. Chemical signals associated with life inhibit necrophoresis in Argentine ants. Proc Natl Acad Sci U S A. 2009; 106(20):8251-8255.

13. Bot ANM, Currie CR, Hart AG, Boomsma JJ. Waste management in leaf-cutting ants. Ethol Ecol Evol. 2001; 13(3): 225-237.

14. Spivak M, Masterman R, Ross R, Mesce KA. Hygienic behavior in the honey bee (Apis mellifera L.) and the modulatory role of octopamine. J Neurobiol. 2003; 55(3): 341-354.
15. Renucci M, Tirard A, Provost E. Complex undertaking behavior in Temnothorax lichtensteini ant colonies: from corpse-burying behavior to necrophoric behavior. Insect Soc. 2010; 58(1): 9-16.

16. Myles TG. Alarm, aggregation, and defense by Reticulitermes flavipes in response to a naturally occurring isolate of Metarhizium anisopliae. Soiobiology. 2002; 40(2): 243-255.

17. Hölldobler B, Wilson EO. The Ants. Cambridge: Harvard University Press; 1990.

18. Hölldobler B, Wilson EO. The Superorganism: the Beauty, Elegance, and Strangeness of Insect Societies. WW Norton \& Company. 2009;

19. Chouvenc T, Robert A, Semon E, Bordereau C. Burial behaviour by dealates of the termite Pseudacanthotermes spiniger (Termitidae, Macrotermitinae) induced by chemical signals from termite corpses. Insect Soc. 2012; 59(1): 119-125.

20. Ulyshen MD, Shelton TG. Evidence of cue synergism in termite corpse response behavior. Naturwissenschaften. 2012; 99(2): 89-93.

21. Chouvenc T, Su NY. When subterranean termites challenge the rules of fungal epizootics. PLoS One. 2012; 7(3): e34484.

22. Haskins $\mathrm{CP}$, Haskins EF. Notes on necrophoric behavior in the archaic ant Myrmecia Vindex (Formicidae: Myrmeciinae). Psyche. 1974; 81(2): 258-267.

23. Purnamadjaja AH, Russell RA. Pheromone communication in a robot swarm: necrophoric bee behaviour and its replication. Robotica. 2005; 23(06): 731

24. Karaboga D, Akay B. A survey: algorithms simulating bee swarm intelligence. Artif Intell Rev. 2009; 31(1-4): 61-85.

25. Gordon DM. Dependence of necrophoric response to oleic acid on social context in the ant, Pogonomyrmex badius. J Chem Ecol. 1983; 9(1): 105-111.

26. Howard DF, Tschinkel WR. Aspects of necrophoric behavior in the red imported fire ant, Solenopsis invicta. Behaviour. 1976; 56: 157-180.

27. Sun Q, Haynes KF, Zhou X. Differential undertaking response of a lower termite to congeneric and conspecific corpses. Sci Rep; In press.

28. Siderhurst MS, James DM, Bjostad LB. Ultraviolet light induced autophototoxicity and negative phototaxis in Reticulitermes termites (Isoptera : Rhinotermitidae). Sociobiology. 2006; 48(1): 27-49.

29. Park YI, Raina AK. Light sensitivity in workers and soldiers of the Formosan subterranean termite, Coptotermes formosanus (Isoptera : Rhinotermitidae). Sociobiology. 2005; 45(2): 367-376.

30. Rollo CD, Borden JH, Casey IB. Endogenously produced repellent from American cockroach (Blattaria: Blattidae): Function in death recognition. Environ Entomol. 1995; 24(1): 116-124.

31. Inward D, Beccaloni G, Eggleton P. Death of an order: a comprehensive molecular phylogenetic study confirms that termites are eusocial cockroaches. Biol Lett. 2007; 3(3): 331-335.

32. Dukas R. Effects of perceived danger on flower choice by bees. Ecol Lett. 2001; 4(4): 327-333.

33. Abbott KR. Bumblebees avoid flowers containing evidence of past predation events. Can J Zool. 2006; 84(9): 1240-1247.

34. Julian GE, Cahan S. Undertaking specialization in the desert leaf-cutter ant Acromyrmex versicolor. Anim Behav. 1999; 58(2): 437-442.

35. Driessen GJJ, Raalte ATV, Bruyn GJD. Cannibalism in the red wood ant, Formica polyctena (Hymenoptera: Formicidae). Oecol. 1984; 63(1): 13-22.

36. Suzuki K, Yoshihama T, Shigematsu Y. Sweeping behaviours of honey bees at the hive entrance. Bull Fac Edu, Chiba Univ. 1974; 23: 273-281.

37. Trumbo ST, Robinson GE. Learning and task interference by corpse-removal specialists in honey bee colonies. Ethol. 1997; 103(11): 966-975.

38. Skidmore B, Heithaus ER. Lipid cues for seed-carrying by ants in Hepatica americana. J Chem Ecol. 1988; 14(12): 2185-2196.

39. Rettenmeyer C. Behavioral studies of army ants. Univ Kans Sci. Bull. 1963; 44(9): 281-465.

40. Diez L, Deneubourg JL, Detrain C. Social prophylaxis through distant corpse removal in ants. Naturwissenschaften. 2012; 99(10): 833-842.

41. Stahel G, Geijskes DC. Ueber den bau der nester von Atta cephalotes L. und Atta sexdens L. (Hym. Formicidae). Rev. Entomol. 1939; 10(1): 27-78.

42. Moser JC. Contents and structure of Atta texana nest in summer. Ann Entomol Soc Am. 1963; 56(3): 286-291.

43. Marikovsky P. On some features of behavior of the ants Formica rufa L. infected with fungous disease. Insect Soc. 1962; 9(2): 173-179.

44. Mabelis AA. Wood ant wars: the relationship between aggression and predation in the red wood ant (Formica Polyctena Forst). Neth J Zool. 1978; 29: 451-620.

45. Chapuisat M. Social evolution: sick ants face death alone. Curr Biol. 2010; 20(3): R104-105

46. Heinze J, Walter B. Moribund ants leave their nests to die in social isolation. Curr Biol. 2010, 20(3): 249-252. 
47. Kramm KR, West DF, Rockenbach PG. Termite pathogens: Transfer of the entomopathogen Metarhizium anisopliae between Reticulitermes sp. termites. J Invertebr Pathol. 1982; 40(1): 1-6.

48. Zoberi MH. Metarhizium anisopliae, a fungal pathogen of Reticulitermes flavipes (Isoptera: Rhinotermitidae). Mycologia. 1995; 87(3): 354-359.

49. Su N-Y. Response of the Formosan subterranean termites (Isoptera: Rhinotermitidae) to baits or nonrepellent termiticides in extended foraging arenas. J Econ Entomol. 2005; 98(6): 2143-2152.

50. Chouvenc T, Su N-Y. Apparent synergy among defense mechanisms in subterranean termites (Rhinotermitidae) against epizootic events: Limits and potential for biological control. J Econ Entomol. 2010; 103(4): 1327-1337.

51. Moore BP. Biochemical studies in termites. In: Krishna K, Weesner FM, ed. Biology of termites. New York: Academic Press; 1969: 233-282.

52. Rosengaus RB, Traniello JFA, Bulmer MS. Ecology, behavior and evolution of disease resistance in termites. In: Bignell ED, Roisin Y, Lo N, ed. Biology of termites: A modern synthesis. New York: Springer; 2011: 165-191.

53. Song D, Hu XP, Su NY. Survivorship, cannibalism, body weight loss, necrophagy, and entombment in laboratory groups of the Formosan subterranean termite, Coptotermes formosanus under starvation (Isoptera: Rhinotermitidae). Sociobiology. 2006; 47(1): 27-39.

54. Park Y, Choe J. Territorial behavior of the Korean wood-feeding cockroach, Cryptocercus kyebangensis. J Ethol. 2003; 21(2):79-85.

55. Nalepa CA, Bell WJ. Postovulation parental investment and parental care in cockroaches. In: Choe JC, Crespi BJ, ed. The Evolution of Social Behavior in Insects and Arachnids. 1st ed. Cambridge: Cambridge University Press; 1997: 26-51.

56. Rosengaus R, Traniello J. Disease susceptibility and the adaptive nature of colony demography in the dampwood termite Zootermopsis angusticollis. Behav Ecol Sociobiol. 2001; 50(6): 546-556.

57. Chouvenc T, Su NY, Robert A. Inhibition of Metarhizium anisopliae in the alimentary tract of the eastern subterranean termite Reticulitermes flavipes. J Invertebr Pathol. 2009; 101(2): 130-136.

58. Milner RJ, Staples JA, Lutton GG. The selection of an isolate of the hyphomycete fungus, Metarhizium anisopliae, for control of termites in Australia. Biol Control. 1998; 11(3): 240-247.

59. Howse P. On the significance of certain oscillatory movements of termites. Insect Soc. 1965; 12(4): 335-345.

60. Rosengaus RB, Jordan C, Lefebvre ML, Traniello JFA. Pathogen alarm behavior in a termite: A new form of communication in social insects. Naturwissenschaften. 1999; 86(11): 544-548.

61. Eisner T, Kriston I, Aneshansley DJ. Defensive behavior of a termite (Nasutitermes exitiosus). Behav Ecol Sociobiol. 1976; 1(1): 83-125.

62. Lindström M, Norin T, Valterová I, Vrkoc J. Chirality of the monoterpene alarm pheromones of termites. Naturwissenschaften. 1990; 77(3): 134-135.

63. Yanagawa A, Fujiwara-Tsujii N, Akino T, et al. Behavioral changes in the termite, Coptotermes formosanus (Isoptera), inoculated with six fungal isolates. J Invertebr Pathol. 2011; 107(2): 100-106.

64. Traniello JFA, Rosengaus RB. Ecology, evolution and division of labour in social insects. Anim Behav. 1997; 53(1): 209-213.

65. Gordon DM. The organization of work in social insect colonies. Nature. 1996; 380(6570): 121-124.

66. Crosland MWJ, Ren SX, Traniello JFA. Division of labour among workers in the termite, Reticulitermes fukienensis (Isoptera: Rhinotermitidae). Ethol. 1998; 104(1): 57-67.

67. López-Riquelme GO, Malo EA, Cruz-López L, Fanjul-Moles ML. Antennal olfactory sensitivity in response to task-related odours of three castes of the ant Atta mexicana (hymenoptera: formicidae). Physiol Entomol. 2006; 31(4): 353-360.

68. Trumbo ST, Huang Z-Y, Robinson GE. Division of labor between undertaker specialists and other middle-aged workers in honey bee colonies. Behav Ecol Sociobiol. 1997; 41(3): 151-163.

69. Robinson GE, Page JRE. Genotypic constraints on plasticity for corpse removal in honey bee colonies. Anim Behav. 1995; 49(4): 867-876.

70. Robinson GE, Page R. Genetic basis for division of labor in an insect society. In: Breed MD, Page RE, ed. The Genetics of Social Evolution. Boulder, Colorado: Westview Press; 1989: 61-80.

71. Julian GE, Fewell JH. Genetic variation and task specialization in the desert leaf-cutter ant, Acromyrmex versicolor. Anim Behav. 2004; 68(1):1-8.

72. Gautrais J, Theraulaz G, Deneubourg JL, Anderson C. Emergent polyethism as a consequence of increased colony size in insect societies. J Theor Biol. 2002; 215(3): 363-373.

73. Jeanson R, Fewell JH, Gorelick R, Bertram SM. Emergence of increased division of labor as a function of group size. Behav Ecol Sociobiol. 2007; 62(2): 289-298.
74. Holbrook CT, Barden PM, Fewell JH. Division of labor increases with colony size in the harvester ant Pogonomyrmex californicus. Behav Ecol. 2011; 22(5): 960-966.

75. Evans TA. Foraging and building in subterranean termites: task switchers or reserve labourers? Insect Soc. 2006; 53(1): 56-64.

76. Crosland MWJ, Traniello JFA. Behavioral plasticity in division of labor in the lower termite Reticulitermes fukienensis. Naturwissenschaften. 1997; 84(5): 208-211.

77. Miura T, Matsumoto T. Worker polymorphism and division of labor in the foraging behavior of the black marching termite Hospitalitermes medioflavus, on Borneo Island. Naturwissenschaften 1995; 82(12): 564-567.

78. Hinze B, Leuthold RH. Age related polyethism and activity rhythms in the nest of the termite Macrotermes bellicosus (Isoptera, Termitidae). Insect Soc. $1999 ; 46(4)$ : 392-397.

79. Johnson BR. Reallocation of labor in honeybee colonies during heat stress: the relative roles of task switching and the activation of reserve labor. Behav Ecol Sociobiol. 2002; 51(2): 188-196.

80. Seeley TD. Adaptive significance of the age polyethism schedule in honeybee colonies. Behav Ecol Sociobiol. 1982; 11(4): 287-293.

81. Wilson EO. Caste and division of labor in leaf-cutter ants (Hymenoptera: Formicidae: Atta): III. Ergonomic resiliency in foraging by A. cephalotes. Behav Ecol Sociobiol. 1983; 14(1): 47-54.

82. Gordon DM. Dynamics of task switching in harvester ants. Anim Behav. 1989; 38(2): 194-204.

83. Lima JT, Costa-Leonardo AM. Tunnelling behaviour of the Asian subterranean termite in heterogeneous soils: presence of cues in the foraging area. Anim Behav. 2012; 83(5): 1269-1278. 